\title{
Reflections of an aging Chicano boomer: Growing old in the time of demographic transformation
}

\author{
Fernando M. Torres-Gil ${ }^{1}$
}

Accepted: 28 September 2021 / Published online: 16 November 2021

(c) The Author(s), under exclusive licence to Springer Nature Limited 2021

\begin{abstract}
This article examines the aging of Latino boomers and illustrates the longevity, policy, and personal challenges and opportunities facing the coming of age of the postWorld War II generation of Latino/as. This treatise, through a reflective lens, posits that with segmented assimilation we can no longer generalize the aging of Latinos as one universal reality based on immigration from rural backgrounds and the existing literature based on traditional cultural norms. The reality is greater variations in how we view the aging process and how we address concerns of health and retirement security and long-term care. We must move beyond notions of perpetual youth to one where we face existential questions: What are the roles and expectations of the new elders in the Hispanic community? What lessons can we impart to younger Latinx cohorts? The author draws on policy analysis to reflect on philosophical questions of Latino/a boomers facing their demographic and longevity destiny.
\end{abstract}

Keywords Demographics $\cdot$ Latino baby boomers $\cdot$ Diversity $\cdot$ Aging

\section{Resumen}

Este artículo examina el envejecimiento de los latinos de la generación de la posguerra e ilustra la longevidad, las políticas, los retos personales y las oportunidades que encara la generación de los latinos nacidos después de la Segunda Guerra Mundial en su paso a la adultez mayor. A través de un lente reflexivo, esta disquisición plantea que con la asimilación segmentada ya no podemos generalizar el envejecimiento de los latinos como una realidad universal basada en la inmigración de orígenes rurales y en la literatura existente basada en normas culturales tradicionales. La realidad presenta variaciones considerables en cuanto a cómo vemos el proceso de envejecimiento y cómo abordamos las inquietudes relacionadas con la salud, la seguridad económica después la jubilación y el cuidado prolongado. Debemos superar las ideas de juventud perpetua y encaminarnos hacia una noción en la que encaramos preguntas existenciales: ¿Cuáles son las funciones y expectativas de los nuevos mayores en

Fernando M. Torres-Gil

torres@1uskin.ucla.edu

1 University of California, Los Angeles, USA

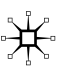


la comunidad hispana? ¿Qué lecciones podríamos impartir a los latinos y latinas más jóvenes? El autor parte de un análisis de políticas para reflexionar sobre las cuestiones filosóficas de los latinos de la generación de la posguerra mientras encaran su destino demográfico y longevo.

Palabras clave Demografía $\cdot$ Latinos de la generación de la posguerra: Boomers latinos $\cdot$ Diversidad $\cdot$ Envejecimiento

Growing old is a visceral reality that all of us must face, albeit in varying ways depending on one's racial or immigrant status, ethnicity, gender, and socioeconomic status. Yet, dealing with this life passage can be disconcerting, to say the least. And to grow old as a Chicano in the twenty-first century after having been socialized by the Chicano movements of the last century is to live through a profound demographic transition. This article is my opportunity to reflect on these developments, and it serves as a philosophical treatise on what all this means-to me, my family, my community and the nation. This can be seen as a selfish endeavor, but my hope is that it will be a constructive exercise in "gerontologizing" my raza and in bringing greater awareness about the social, economic and policy importance of gerontology and geriatrics to our longevity. What is revealing in this analysis is that the Latino community faces a paradox: overall they have the highest life expectancy (primarily Mexicans and Cubans, with Puerto Ricans somewhat lower) compared to Blacks and Whites, yet will face greater levels of health and retirement insecurities.

I am now entering my eighth decade, and I look back on what I've experienced and what it might mean in terms of life lessons. I came of age in the middle of the last century, at the cusp of a baby boom population growth that resulted in up to seventy-six million people born in the United States between 1946 and 1964 (Myers 2007). This is the fabled post-World War II generation that created a cultural revolution and influenced much of society's values around individualism, civic activism and popular culture (e.g., music, dress, leisure). This generation grew up at a time of social and political upheaval, with the Cold War, the civil rights movement, assassination of public figures, urban riots, the Vietnam War and, later, the stagflation of the 1970s - all of which resulted in a conservative backlash: the Reagan Revolution and downsizing of government. Since those times, the United States has faced an everwidening set of social and economic disparities (especially affecting communities of color), which today are at a point not seen since the 1920s and 1930s. Ironically, as we baby boomers, whether Latino, Black, Asian/Pacific Islanders, or White, reach our later years, we now realize how good life was in terms of the post-World War II economic prosperity and social advances that, by 1980, had begun to shift (Hacker 2006) toward social and economic cleavages. As we reach what we thought would be our golden years of retirement, we find that the social upheavals of 2020 - pandemics, social protests, economic recession, climate change-are both a reminder of what we faced fifty years before and a rude awakening in terms of our old age. Are we prepared for becoming elders? Do we have the retirement and health security we envisioned? What does growing older mean for our personal relationships with 
family, friends and communities? Is our longevity a gift or a bittersweet reminder of life's vicissitudes?

The purpose of this treatise is to provide a personal and a policy perspective on what it means to grow older as a Latino, Chicano and baby boomer. It provides not only a demographic and factual context but also a series of reflections that I hope will engender interest among the emerging Latino communities, and acceptance by all of us that we should face, not fear, living longer and moving into our elder years. The ultimate irony is that as aging Chicano baby boomers become senior boomers, we are facing multiple sets of both challenges and opportunities. We are challenged with aging and seeking health, income, and retirement security in our old age. We are challenged with maintaining social support networks of friends and families. We are facing the realities of caregiving and long-term care for our parents, as well as for ourselves. And we are facing the inevitable legacy questions: What have we done with our lives? Did it work out the way we hoped it would back in our youth? And do we still have the time, ability, and energy to contribute to the current crises facing this country and to provide support for emerging Latinx populations as they face their struggles? These and other questions become paramount as we realize that we may yet live into our eighties and nineties and even become centenarians-all while we face the loss of dear friends, family members and colleagues and stare into endof-life realities.

This essay about gerontology and its connection to Hispanic aging, reminds me of my first introduction to this fascinating field of study. I was just a twenty-two-yearold and a first year graduate student (the Heller School) at Brandeis University, and my adviser offered me the chance to earn extra dollars by evaluating a conference in Washington, DC. As a "starving student" how could I say no to an all-expensepaid trip and compensation! Little did I know that this 1971 White House Conference on Aging would turn my life and career in new directions. I returned to Brandeis excited about this new field, and as I explained it to my Chicano friends attending other Boston area universities, pursuing traditional fields of law, education, medicine, business (we were the first large contingent of Hispanics from the Southwest to attend elite New England schools), they would respond with variations of "What is that? ... Sounds depressing to work with old people ... You might never get a job in this new field about aging." Well, I persevered, and today, fifty years later, I've lost count of all those friends who came to realize how the study of "aging" impacts all disciplines from law (elder law) to medicine (geriatrics) to business (senior consumer market) to social work and urban planning (mental health, housing, transportation) and, of course, to public policy (the politics of aging, Social Security, Medicare). The demographic trends I studied in the early 1970s have become unescapable demographic realities by 2020 .

\section{The contextual factors: The demographic trends}

The United States of America is aging, as is most of the world. Today, $15 \%$ of the US population is sixty-five years of age and older, and that is projected to grow to $20 \%$ by 2050 (Torres-Gil and Angel 2019). Those numbers represent the 
post-World War II population, with seventy-six million born between 1946 and 1964. When you factor in those who have passed away and an influx of immigrants who are in that age bracket, we can expect up to eighty million in that baby boom cohort. By 2029, all of us in this cohort will be sixty-five and older, doubling the current number of elders. In our policy research at UCLA's Center for Policy Research on Aging, we found that roughly $10 \%$ of this cohort is Hispanic, giving us about eight million Latinx baby boomers.

At the same time that the United States is aging, it is also witnessing declining replacement levels (also known as fertility rates). It takes 2.1 children per child-bearing female to maintain current population levels (Saenz 2015). Anything higher than 2.1 is a net increase, and anything lower is a net decrease. The United States faces a peculiar nexus of diversity and replacement rates. Left to non-Hispanic Whites, the overall replacement level would be well below 2.1 (specifically 1.8), yet the US population continues to increase. Why? Latinos, Asians and immigrants! Replacement levels for first-generation Latinos-mainly Mexicans and Central Americans, including undocumented persons-are well above 2.1, while Puerto Ricans and Cubans are at 2.1 and falling. Levels for Asians, especially Koreans, Chinese and Pacific Islanders, are generally above 2.1, while African Americans are at 2.1 and declining. Yet, we must note that since the Trump years (with its intense xenophobia limiting immigration) and pandemic (declining life expectancy), it appears that overall replacement rates for all groups has declined, leading to concerns about workforce shortages. So, what does this tell us? The United States population will become majority-minority by 2050 , with Latinos accounting for the largest ethnic group and Asians having the highest proportional increase. The future, then, will be less White and Black and more Hispanic and Asian (Torres-Gil and Angel 2019) with growing proportions of mixed race/ethnic individuals.

As I tell my Chicano studies students who worry intensely about the anti-Mexican, anti-immigrant nativism of the Trump years: "Keep this in perspective: You've won!" And I provide them with these trends to reinforce that, demographically, the Latino population will continue to win. However, this begs the question: Will those numbers translate into economic, social and political power? Can we expect a decent quality of life in our old age?

\section{The aging of the Latino population: Good news and not-so-good news}

Which brings us to the realities of our aging. An added trend is that Hispanics have a higher life expectancy rate than Blacks and Whites in the United States. For some mysterious reason, referred to as the "Hispanic paradox," we (primarily Mexican Americans and Cubans) will live longer than Whites and Blacks and have roughly the same life expectancy as Japanese, Chinese and Korean populations (who have the highest life expectancy rates), although there is a gender differential, with women continuing to outlive men by about five to seven years. 
What does this mean for us in terms of contextual factors? Here, the picture is mixed and brings out challenges we must confront as we age as an ethnic group. We have advantages and disadvantages.

First, the good news: Latinos_-including Cubans, Puerto Ricans, Mexicans, Central Americans and undocumented immigrants - continue to maintain stronger personal, social and familial supports into second and third generations, which helps to mitigate adversity, nativism and economic struggles (Miyawaki 2016). We are more likely to retain family ties and intergenerational relations and to support one another by raising other people's children, giving hard-earned dollars to needy family members, inviting relatives into our tight households and other means. We still, by and large, believe in the American dream: If you work hard and play by the rules, your children and grandchildren will have a better life. Thus, it's no surprise when we see on street corners or freeway offramps Latinx undocumented immigrants selling produce or working in "taco trucks" to get their first toehold in the American economy. This, of course, may overromanticize our resiliency; and we know that, by later generations, those attributes of the Hispanic paradox begin to dissipate as we become "more American." But that resiliency, culture, and tradition enables first-generation Latinos and immigrants (and later generations) to persevere in the face of adversity.

The not-so-good news is that we face big challenges as we age as Latinos in these momentous times. First, our retirement security is not secure (Bravo et al. 2015). Compared with Blacks and Whites, Latinos have the lowest participation in defined benefit plans (pensions) and the lowest retirement savings in defined contribution plans (401(k)s). Yet we have one of the highest life expectancies and thus will find that our retirement savings, should they exist, must last longer. On the other hand, we rely on Social Security (OASDI) as a sole source of retirement income at a greater rate than Blacks or Whites (NCLR 2015). This double-edged sword means that we are vulnerable to any Republican efforts to downscale the one secure retirement plan we can count on: Social Security. Of course, that assumes you are a legal citizen. Our health security is at risk. Latinos have the lowest rates of health insurance coverage compared to Whites and Blacks. We find among younger Hispanics growing incidences of chronic conditions and diseases such as diabetes, obesity and high blood pressure. In particular, Hispanic women find their longevity dividend (living longer) precarious, given that their retirement security lessens as they age and their chronic conditions lead to disabilities as they grow older. Fortunately, we have Medicare, Medicaid and the Affordable Care Act to provide a health safety net. But again, this all depends on the extent to which conservatives, who vow to dismantle these programs, can be held at bay.

These are the most glaring aspects of longevity for the growing Hispanic population: we will grow in numbers, live longer, in time have fewer children, and, as elders, be the most dependent on public benefits to provide a modicum of retirement and health security. So where does this leave us in reflecting about age and aging? 


\section{Time travel: Back to the future of my personal journey}

Before laying out the realities of aging as Latinos and the new realities of becoming ancianos and abuelos, I think back on my family's journey to the United States. Like many of us, my family came as undocumented immigrants. My grandparents fled Mexico shortly after the Mexican Revolution and established themselves in California. As farmworkers, they traveled the state's migrant trails, from Southern California to the Great Central Valley (San Joaquin) and the coastal valleys (Santa Clara, Salinas, Santa Maria). The Great Depression was rough: they slept on roadsides and in campgrounds, shared food and child care, and dealt with discrimination and tough working conditions. Yet they were stoic, resilient and religious; no victims were they. They finally settled in a village on the Monterey Bay (Castroville), built a house and grew their family. My ten aunts and uncles were first-generation Mexican Americans. Despite their share of hard work and discrimination, my uncles proudly served in the US military during World War II and the Korean War, and their wives dutifully raised their Chicano boomers. And thus, I, along with my cousins (seventy-three of us) and siblings (nine brothers and sisters), grew up in California in this bicultural/bilingual world, living our Mexican traditions yet seeking to become Americanized. It was this heritage that led me and many of my cousins and siblings to become active in the Chicano movements of the 1960s and 1970s, to fight against that discrimination and the lack of equal opportunities that our parents and grandparents faced. To establish our own identity as a new raza combining what we felt was the best of two worlds. We came of age during what is now referred to as America's Golden Age: a period of unprecedented prosperity and stability that, notwithstanding the turmoil of the civil rights movement, Vietnam, protests and political intrigues (Nixon's resignation), enabled us to do quite well. We benefited from affirmative action, bilingual education, rising wages and available jobs. Today, of my nine siblings, eight are retired, all have pensions (from government and the private sector), and most are married with children.

For myself, after volunteering with the United Farm Workers, I went to graduate school and was one of the first Latinos to study gerontology (the first being the legendary Professor Leo Estrada). With my graduate degrees, I moved into a career that gave me great personal and professional satisfaction, including serving three US presidents, heading a congressional committee, and achieving tenure at two leading universities. My personal life includes a wonderful spouse and family and becoming a patriarch for my extended clan while enjoying the fruits of this career with pensions for my wife and myself, equity from our two properties, retiree health care and defined contribution savings. Ah, we have it all! Or do we? What does it mean that we did well? What story does it tell that my wife (also a child of Mexican migrants) and I achieved a good life in our later years? Are we living an illusion? Did we give up and sacrifice fundamental values and traditions (such as staying in our barrio with kin and neighbors, having our parents live with us in their old age, passing on Mexican traditions to our grandkids, remaining fervent Catholics, limiting our world to Mexico and Mexicans)? Herein lies a set of other perplexing issues facing us in our retirement. Will our children do better or worse than us Latino boomers? 
Facing the specter of aging and coming to terms with the fourth quarter of life will, for everyone, but especially Latinos growing old at this time, requires that we face these existential issues.

\section{The longevity dividend: How will we use our expanded lifespan?}

"Aging is not for sissies." This is a line by the famous Maggie Kuhn, founder of the Gray Panthers. It is about perseverance, strength and fortitude as we move into our later years. We will all face the vicissitudes of aging, such as declining health, chronic conditions and lessened mobility. Yet this does not detract from us enjoying the last decades of our lifespan. It also implies that we have a purpose and that we continue to give back as best we can, whether by mentoring, voting, politics, volunteer work or some other activities. It means that we shed outdated notions of youth and vitality that are often reinforced by marketing and social media: we can be older, have mobility limitations and enjoy our wrinkles. Growing older is to enjoy memories and the present and to give back. As a Latino boomer who is aging with a disability (a polio survivor), I take advantage of our Downtown Los Angeles condominium, where I can use my motorized mobility scooter to enjoy the cultural benefits of this metropolis, including institutions like Walt Disney Concert Hall and The Broad art museum, knowing that the Americans with Disability Act requires fully accessible curb cuts, sidewalks and ramps.

Bravely facing the realities of growing old, we now have the opportunity to be role models and leaders for younger generations, to give back and to find ways to educate, inform and influence. By now, Chicano boomers will be entering their seventh or eighth decade and, if fortunate, will enter their ninth at some point. How do we work with Latino Gen Xers (those now in their forties to mid-fifties), Millennials (in their midtwenties through thirties) and the upcoming Gen $\mathrm{Z}$ (twenties and younger)? The politics and agendas of younger cohorts may differ from those of baby boomers. These cohorts are more invested in the Black Lives Matter movement; more closely connected to Mexico, Puerto Rico and Central America; more likely to be fluent in Spanish and English (many of my Chicano activist friends did not speak Spanish since their parents felt compelled to focus on assimilation to minimize discrimination); and more likely to be cognizant of the glaring social and economic disparities that have been building since the 1980s. In particular, Gen $\mathrm{Z}$ may be the first generation to face downward mobility and be less likely to reach their American dream of achieving a higher standard of living than their parents. In my Latino Social Policy course, for example, I've noticed a disquieting shift in the last few years in the optimism expressed by my students; more are likely to express that the American dream is no longer possible. Yet, despite this heightened sense of legitimate cynicism, there is much we can do to support them. While we vote to protect Medicare and Social Security, for example, we should support their efforts for universal health care, affordable college education and a guaranteed minimum income. On my part, I am the faculty adviser to our UCLA undergraduate clubs on aging and Alzheimer's disease, and I revel in my former students' training to be gerontologists and geriatricians in medical school and schools of public health. With 
my Chicano studies students, I serve as a mentor, connect them to internships and postgraduation employment, and always provide letters of recommendation.

\section{Taking care of our own: The romantic illusion}

We grew up at a time when our parents and grandparents, in most cases, took care of elders and the disabled in their own homes and avoided the stigma of nursing homes and mental health services. Many of us still hold the illusion that we will have our parents move in with us when they can no longer take care of themselves. Yet the realities are that most couples need to work, there are fewer children, and many will not have the capacity or even the willingness to care for their elders. For better or worse, this reflects American values of individualism and ageism. Yet there is a way to reconcile our cultural penchant to care for our elders even if we are fiscally and geographically unable to do so because, for example, our home is too small, we live far away, or we can't take time off from work. Promoting long-term care services and supports is about supporting adult day health centers, in-home supportive services, personal attendants, zoning that allows detachable units (aka granny flats) on single-family home properties, and otherwise advocating not just for universal health care but also for universal longterm care that provides services and financial support for caregiving in the home, in the community, and, where necessary, with culturally competent long-term care facilities. Today's reality is that these services are not available unless you are wealthy (and can self-fund), purchase expensive long-term care insurance or you "spend-down" to poverty levels to qualify for Medicaid and its stringent criteria (and accept lower-quality nursing home and home health care).

Caregiving for others and for ourselves will be a key existential issue as we age. My wife and I took care of our parents as they aged, and our many siblings generously helped with finances, caregiving and home health care. But a number of us have few or no children. So how will we face our caregiving needs? In our case, my wife and I (we both have long-term care insurance and have savings) have identified a continuing care retirement community with the full continuum of independent living, assisted living, skilled nursing care and memory care. We continually nurture our relationships with family and close friends and draw on reciprocity as an element of supporting one another (also known as the Village Movement). Intriguingly, we have Chicano friends who have retired in Mexico (more than two million US citizens are retired in places like Lago Chapala, San Miguel de Allende, and Baja California) to take advantage of lower housing and medical costs and a low-cost labor force. Yet a word of caution: Medicare does not extend outside the US, and as those retirees become more dependent, they are beginning to realize what they have left behind in the US in terms of relationships and medical care. 


\section{Retirement insecurity and the feminization of aging}

The preceding assumes we are receiving a pension and Social Security, that we have saved sufficient funds, and that our home equity gives us additional capital. Yet this is the case for only a small segment of us Chicano boomers. Many more do not have these resources and face retirement insecurity, making them heavily dependent on Social Security and possibly a reverse home mortgage (where you can draw on the equity and live in your home, but it goes to the lender when you pass away). And then there are those who will need the means-tested public benefits geared for low-income and disabled elders: Medicaid, in-home supportive services, and Supplemental Security Income. Social Security Disability Insurance and Older Americans Act services such as home-delivered meals and senior programs.

The issues of aging and retirement security ultimately are about women and their aging experiences. With gender differentials in life expectancy, poverty and vulnerability will loom over Latinas. Whether they are spending down to care for a husband, using retirement savings to support children and grandchildren or growing old as a single individual, aging becomes a crucial issue for Latinas. Latinas are also likely to be home-care and long-term-care workers for others (e.g., in nursing homes and board and care facilities), yet with minimum wages and few benefits. Surprisingly, as interest has grown in scholarship and policy research on Latino aging, very little has focused on the issues, experiences and dynamics of women (and LGBTQ) as Hispanics, as abuelas and as ancianas. In part, this may reflect the successes of younger and middle-age Latinas who are advancing in education and the professions (a career focus). In part it also reflects that demographic reality that as Latinas do better, they tend to have fewer children and exercise choices about relationships and marriage. Many, however, who do have children, find themselves in the "sandwich generation" having to care for older parents and children while struggling to work. Increasing numbers are aging as single persons: never married, divorced, widowed. Others find themselves as grandparents raising grandchildren because their offspring for various reasons (drugs, divorce, mental health) cannot cope with childrearing. We have new factors to examine in the feminization of Latina aging: What are the issues they face with longevity and how do they balance their aspirations as individuals, partners, parents, singles, child free or with children? How ought we to educate younger Latinas about the possibilities of a long life and planning ahead to ensure they are financially astute and can enhance their retirement and health security? And, not last but important, what role can Latinas play in public policy and advocacy of programs and services for an aging Hispanic population? These and other issues are a new frontier in gerontology, gender and LBGTQ studies and LatinX/Chicana/Chicano studies.

\section{End-of-Life (EOL) and loss is the actuarial inevitability}

One reality that cannot be avoided is our ultimate demise: We will all reach the end of our lifespan. Are we prepared? Have we organized the basics: a will, trust, funeral arrangements, medical directives? In addition, have we taken advantage of our 
cultural traditions of integrating, discussing and sharing how we want to reach the end of life? This is about hospice, palliative care, death with dignity and the spiritual dimensions of accepting life's ultimate ending. The movie Coco and our tradition of Day of the Dead give us a popular image of welcoming this actuarial inevitability. My wife and I have fulfilled the legal aspects of end of life and have prepared our wills, trust, and advance health directives as well as the familial and personal EOL requirements by providing written letters of instructions to our family about our final wishes regarding internment, celebrations and distribution of assets.

Loss will be a big factor for all of us; the death of family members, long-time friends and work colleagues will be bittersweet moments in our transition through elderhood. By now, most baby boomers have lost their parents-a profound loss. In my family, eight of ten aunts and uncles have passed away (and the remaining two are in their eighties.) In the last few years, I've attended many funerals for lifelong childhood and college friends, as well as family members. I remind my siblings and cousins that as parents and relatives leave us, that "our turn is next," and I do so to encourage them to face bravely end-of-life realities; it can be traumatic but it can also be spiritually and life affirming.

\section{Reconnecting to our legacy}

As we contemplate all these factors related to aging, gerontology and geriatrics, and as we incorporate our unique portfolio of being aging Latinos, let us remember that whatever legacy we envisioned in our youth, the real impact Latinos have in the United States is that we will become the largest ethnic group by 2050 . This does not guarantee commensurate political and economic power, but with sufficient education and Latinx leadership, our hope is that numbers translate to influence. Notwithstanding Asians and Pacific Islanders, who have the highest growth rates, and other refugees and immigrants, the United States will become Latinized, as non-Hispanic Whites and Blacks account for a lower proportion of the population. With their lower median age and higher fertility rate, Latinos will keep the United States younger. Yet Hispanics will also age, and today's K-12 Gen Z may well reach the next century (2100). Thus, in our elderhood, there is much we can do to inform, mentor and support younger generations and otherwise continue an intergenerational legacy in which we serve as elders yet do our part to prepare this nation for the blessings of immigrants and diversity. Immediate priorities include supporting DACA and DREAMers and advocating for immigration reform that provides a pathway to citizenship. Broader goals will be encouraging multiethnic and multicultural coalitions to ensure that, as the US population becomes majority-minority, it maintains its north star of "E Pluribus Unum": out of many, one. I firmly believe in the founding documents of this nation-the Declaration of Independence, the US Constitution, the Bill of Rights_-as aspirational goals to work toward. And, as an unabashed patriot, I believe in our country and welcome diversity and will do my part to promote adherence to these values. We want our young Latinx generation to grow up in a nation united and to view the Trump travesty as an aberration in this country's long quest for true greatness. 
My professional and policy career gives me an abiding faith in the grand experiment known as "the Act of Democracy," whereby our political institutions and constitutional checks and balances give a large measure of opportunity and influence. Granted, I am an "institutionalist" in that I believe in this system of government. As President Carter's appointee to the Federal Council on Aging, I had my first entre to elite networking (working closely with the first lady, Roslyn Carter and the secretary of HEW, Joseph Califano) in promoting policies on caregiving, mental health and long-term care. I served as a White House Fellow in the Carter administration, overseeing immigration and refugee affairs, and had a direct role in decisions by the White Houses to rescue Vietnamese boat people escaping the communist regime. During the 1980s I worked as staff director of the US House Select Committee on Aging under the sponsorship of my mentor, Congressman Edward R. Roybal, the godfather of Latino politics in Los Angeles. I had the opportunities to work on several presidential campaigns as an issues adviser (Michael Dukakis, Al Gore), which brought me to the attention of a little-known southern governor, William Jefferson Clinton, waging an uphill presidential campaign against an incumbent. As a good solider I served as an issues adviser in the California campaign and, to our pleasant surprise, Bill Clinton became president and I was nominated (with Senate confirmation) as the first US assistant secretary on aging in DHHS. My third presidential appointment was my nomination by President Barack Obama as the vice chair of the National Council on Disability (with Senate confirmation). In these latter roles I was able to directly manage agencies serving older adults and those with disabilities and to be a policy entrepreneur in both administrations.

What does all this signify in growing old during a time of demographic transformations? I feel as if I've been a witness to history and the policy and political happenings of the last fifty years. I take great satisfaction that I did some good for older persons, persons with disabilities, communities of color and the disadvantaged. I retain faith in the civic and institutional norms of our democracy and its systems of checks and balances and self-correction. Yet, none of this can be taken for granted. The election of Joe Biden and Kamala Harris is cause for rejoicing, yet the unprecedented disrespect by the outgoing Trump administration and its betrayal of our basic institutional safeguards tells me that we have to recommit ourselves to educating and inculcating to our Latino/a community a similar commitment and belief in the sanctity of our democratic institutions. As a seventy-two-year-old who served as a policy volunteer for the Biden/Harris campaign, I have faith in their integrity and effectiveness, and I would be willing, despite my physical limitations, to serve in a part-time capacity (advisory committee, task force) and to continue my efforts to prove that the USA still provides for the American dream.

\section{Final thoughts}

And so, it has come to this stage in the life cycle. The coronavirus pandemic has a silver lining: facing the reality of mortality. The realization that COVID19 respects no one's long-term plans pushed me to update all of my EOL documents and to process my legacy. I am coming to terms with the fact that I did 
accomplish many good things but that other goals were not fulfilled; that I can forgive and be forgiven for possible transgressions; and that I should put on paper my memoirs. My wife has pushed me for many years to write my autobiography and organize my files. Although we may feel that our life stories are not particularly interesting, I learned in a memoir-writing course that unless we write our version of history, there will be no history about us. Thus, I am increasingly writing and organizing my thoughts, feelings and experiences, and in a manner that can be passed on to other generations, whether they find it interesting or not. I can say that as an elder entering my eighth decade of life, I did pretty well: I have a wonderful wife and family and a satisfying career, and we have many young people in our lives (taking seriously our roles as aunt and uncle, godparents and surrogate grandparents) and dear friends. I'm also now focused on "purposeful aging" by contributing to the best of my physical and mental energy. This includes participating on boards and commissions that are serving the homeless, advocating for Hispanic youth and promoting programs for older persons and those with disabilities. I believe that, should I unexpectedly leave this Earth, I can do so with minimal regrets and a sense of peace knowing that I've taken care of my family financially and that I've closed the circle of relationships and life. And on my gravestone (located on the Monterey Bay where it all began) will be a particular passage from T. S. Eliot's “The Four Quartets”:

We shall not cease exploring

And the end of all our exploring

Will be to arrive where we started

And know the place for the first time.

\section{References}

Bravo, J., N. Mun Sim Lai, G. Donehower, and I. Mejia-Guevara. 2015. Aging and Retirement Security: United States of America and Mexico. In Challenges of Latino Aging in the Americas, ed. W. Vega, K. Markides, J. Angel, and F. Torres-Gil, 77-92. New York: Springer.

Hacker, J. 2006. The Great Risk Shift. New York: Oxford University Press.

Miyawaki, C. 2016. Caregiving Practice Patterns of Asian, Hispanic and Non-Hispanic White American Family Caregivers of Older Adults across Generations. Journal of Cross Cultural Gerontology 31: 35-55.

Myers, D. 2007. Immigrants and Boomers. New York: Russell Sage Foundation.

NCLR. 2015. Enhancing Latino Retirement Readiness in California. Washington, DC: National Council of La Raza.

Saenz, R. 2015. The Demography of the Elderly in the Americas: The Case of the United States and Mexico. In Challenges of Latino Aging in the Americas, ed. W. Vega, K. Markides, J. Angel, and F. Torres-Gil, 197-224. New York: Springer.

Torres-Gil, F., and J. Angel. 2019. The Politics of a Majority Minority Nation: Aging, Diversity and Immigration. New York: Springer.

Publisher's Note Springer Nature remains neutral with regard to jurisdictional claims in published maps and institutional affiliations. 
Fernando M. Torres-Gil is UCLA Professor of social welfare and public policy and director of the UCLA Center for Policy Research on Aging. He holds a joint appointment as a USC adjunct professor of gerontology. His research focuses on issues of diversity, aging, immigration and disability policy. His academic work is informed by extensive public policy experiences with three presidential administrations and as a staff director in the US Congress. 